\title{
The Life Cycle Model of the Fertility Choice in Hungary*
}

\author{
Petra Németh
}

In this paper, we model the Hungarian fertility choice at the micro level. We outline a life cycle model in which a representative family makes decisions on its number of children, the timing of having children and the mother's return to work after having children over the course of its life cycle. In constructing the model, we incorporate the factors influencing the decision to have children (with a particular emphasis on the family benefits scheme between 2006-2014) and how the behaviours of various household types (in terms of qualifications) differ from each other. According to the simulation results, among the family support tools presented, the family tax allowance scheme introduced in 2011 has a significant impact on the final number of children, maternal age and the timing of childbearing among low and medium education families. The measures introduced in 2014 provide incentive to have three children in all educational groups and foster the early labour market return of mothers. To our knowledge, no similar modelling attempts have been made so far in the Hungarian literature.

Journal of Economic Literature (JEL) codes: C61, D91, H31, J13, J18

Keywords: childbearing, family support, life cycle model

\section{Introduction}

The objective of this paper is to model the decision to have children in Hungary at the micro level, in order to expand the current body of material on this topic. In constructing the model, we incorporated the domestic factors influencing the decision to have children (with a particular emphasis on the family benefits scheme) and how the behaviours of various household types (in terms of qualification) differ from each other. To our knowledge, there have been no similar attempts to date in the Hungarian literature to create a model for the optimal timing of having children.

A substantial body of literature exists on the modelling of women's fertility and labour decisions, but the modelling technique vary widely. The foremost

\footnotetext{
* The views expressed in this paper are those of the author(s) and do not necessarily reflect the offical view of the Magyar Nemzeti Bank.

Petra Németh is assistant professor at the Department of Macroeconomics of Corvinus University of Budapest. E-mail: petra.nemeth@uni-corvinus.hu
}

The Hungarian manuscript was received on 30 June 2017.

DOI: http://doi.org/10.25201/FER.16.4.535 
representatives of one of the main directions describe women's fertility and sequential labour supply decisions in a dynamic model, also known as the life cycle model under specific circumstances and conditions. The common feature of these models is that they assume optimising economic agents and factor in all direct and indirect costs and benefits associated with having children. Solving or structurally estimating these types of dynamic models gives us answers to several key questions such as family policy allowances and the role of childcare institutions in life cycle decisions, as well as explanations for decreasing fertility, changes in female labour supply and the differences in the fertility and labour supply decisions between countries (Arroyo - Zhang 1997, Hotz et al. 1997, Francesconi 2002, Del BocaSauer 2009, Bick 2010, Keane - Wolpin 2010). In this model framework, we can also investigate not only the optimal number of children, but also the optimal time interval between births.

Hotz, Klerman and Willis (1997) and Arroyo and Zhang (1997) provide a broad overview of the structure, characteristics and solvability of the dynamic or life cycle model investigating the fertility decision, while the work of Gábos (2005) provides a summary in Hungarian. Francesconi (2002) estimated a dynamic structural model in which married women make labour supply and fertility decisions. Women differ according to their full-time or part-time work status. The model yielded an important result in several regards, of which the most relevant one for our topic is: if the mother works full time and has a child, she will achieve a significantly lower lifetime utility if she stays off the labour market for an extended period after childbirth compared to staying off the labour market for a short period. However, this difference is negligible among women with part-time work. Keane and Wolpin (2010) also used a structurally estimated life cycle model to quantify the extent to which the difference in preference, the available welfare services and differences in labour market opportunities determined the life cycle decisions of Spanish women with various characteristics. Del Boca and Sauer (2009) estimated a decision rule derived from the life cycle model using data from Italy, France and Spain and drew conclusions from this on the link between the institutional environment, labour market flexibility, childcare institutions and activity and fertility decisions. Bick (2010) investigated two reforms recently introduced in Germany using a life cycle model calibrated to German data. His main line of investigation is the role of subsidised early childhood childcare in the life cycle labour supply of married women and their willingness to have children. Based on the results of the model, Bick (2010) concludes that the labour market activity and fertility of women with children under three years of age is positively influenced by the availability of subsidised crèches.

Mainly tied to Bick's (2010) paper, we build a microeconomics-based dynamic or life cycle model to determine the optimal childbearing strategy for Hungary that 
factors in the fertility choice, resuming work after having children and the temporal links between the factors shaping the decision to have children and the mechanism of action between them. Accordingly, we would like to lay the foundations of a life cycle model that takes into account and factors in to such extent as is practicable the domestic economic and institutional factors and environment that influence/ determine a family's fertility decisions and the subsequent return to work. These factors are: daytime childcare options for young children; the mother and father's education, labour market status and labour income; family allowances and tax rules. Among these, we focus particularly on investigating the role of family policy tools on fertility decisions. We would like to especially emphasise that - for modelling purposes - we ignored every other factor that we knew has or may have a significant impact on fertility choice, including changes in values, the spread of new types of relationships, cultural and biological factors or the family's housing conditions. In summary, we outline the life cycle decisions of women having completed their studies, but still of childbearing potential given the specific support and paid leave system, while the model's resolution is based on comparing the direct and indirect costs and benefits of having children.

The model ultimately shows that given a specific support environment, when to have children and how many children are optimal with how much labour market absence for families is characterised by different parameters (different education). In other words, the model gives us an answer as to how the many transformations of the family benefits scheme influence families' optimal childbearing and in what direction, all other things being equal. Based on the model, we also attempt to offer an explanation to in-depth questions such as which benefits affect the timing of childbearing and which benefits foster a quick return to the labour market; which benefits best contribute to childbearing by families with various degrees of education; how does the optimal childbearing strategy of families with different degrees of education differ under a specific benefits system. We look at three various family support regimes: the regime prevailing in 2006-2010, the one in 2011-2013 and the new legislative package on support and paid leave for mothers with small children adopted in 2014 (referred to as GYED-extra).

In the following, this paper is structured as follows: After the introduction, we outline the life cycle model and its resolution in Chapter 2 and provide and calibrate the model's parameters. In Chapter 3, based on the model's simulation results we present how a specific support and tax scheme influences the life cycle decisions on childbearing and female employment of families with different degrees of education, while Chapter 4 summarises the results of the model and presents the final conclusions. 


\section{The life cycle model of fertility choices under various family benefits schemes}

In accordance with the literature, the model features the following general characteristics: It is first made up of a man and a woman who make a decision on their number of children and the timing of childbearing, on the utilisation of their time and incomes during their life cycle. The couple maximises its lifetime utility characterised by constant preference ordering ${ }^{1}$ given specific time and budgetary constraints, and given the factors shaping the number of children and the raising of children and the technological constraints shaping the woman's productivity. The man and the woman's human capital increases with age/experience (and, as a result, their labour income), but at a decreasing rate, and the mother's human capital amortises during the time spent at home on maternity leave, in other words if she leaves the labour market (Bartus et al. 2013). In terms of the general structure, we supplemented or simplified the known modelling framework in several regards (adjusted to the Hungarian environment) and thus work based on the following specific life cycle model.

A typical family's joint life cycle decision on having children and working is considered realistic at different ages depending on its level of education, but the model investigates a 20-year period uniformly for every level of education. We also assume that the start of work is also the potential start of the option of having children irrespective of the degree of education. We determined the age for starting work based on the age published in the 2012 Hungarian Labour Market Yearbook and corresponding to the starting age for earning included in the 2011 age-income profiles: the examined career begins at age 18 for the unskilled and those with low qualification, at age 20 for those with medium qualification and at age 25 for those with high educational qualification (Fazekas - Benczúr - Telegdy (edit.) 2012:372, Figure 6.3.4). In addition, in line with the data, we can also assume that most women in Hungary currently have a child before the age of 45 and most women have their first child before the age of 30 on average (KSH 2015:53, Table 4.1.3).

We know, however, that having a child is a lifelong commitment and can be a significant cost/benefit for the family until the child turns 25 . It would therefore be warranted for the couple to consider its decision to have children in light of their entire lifetime. However, we rejected this option for two reasons. For one, in line with the literature, we also use the simplifying assumption that borrowing or saving is not possible in either period (Arroyo - Zhang 1997; Hotz et. al 1997; Francesconi 2002; Del Boca - Sauer 2009; Bick 2010; Keane - Wolpin 2010). For this reason, we are unable to model either the flow of wealth between nations or long-term

\footnotetext{
${ }^{1}$ This assumption is important because we are currently not looking at the effect of changes in preference, that is, of changes in value on fertility.
} 
care for the child in this framework. The other reason is that we do not think that someone who is planning to have a child in the near future is able to calculate or thoroughly consider the associated costs over the long term, i.e. over the next $20-25$ years. Even if they could, it is improbable that this would substantially change their current decision.

The woman is the household's actual decision-maker, meaning it is she who decides during every period on consumption, childbearing and, if she has a young child, on labour, while the man has a passive role and works during every period (with the exception of families with education of less than eight years of elementary school) (Hotz et al. 1997; Keane - Wolpin 2010; Fehr - Ujhelyiova 2011). We assume that in periods when the family has no young children or does not yet have any young children, the woman works full time (except if the mother has education of less than eight years of elementary school, in which case she remains inactive throughout her entire lifetime). However, if there is a small child under the age of three in the family, the woman can decide about returning to work. Furthermore, each family can have three children at most in the model, only one child can be born per period ${ }^{2}$ and the woman dedicates all of the time to child-raising in the years when a child is born. After they are born, the children consume similarly to their parents, and if the mother works, the children require childcare during early childhood (e.g. public crèche, family day-care, private crèche). We do not differentiate between the raising of children in the model, ${ }^{3}$ which may be a function of how much different parents spend on their child's education and training. For the sake of simplicity, we assume that free pre-school and school is available for every child at the same standard, and therefore we regard the cost of caring for children over the age of three as zero. We do not incorporate it into the model that the costs of raising children may change as a function of the child's age and the parents' education (Bartus et al. 2013).

In the model, we distinguish between families based on the parents' highest level of completed education. Investigating based on education is warranted for several reasons. For one, the productivity of an unskilled couple, a couple with low qualification, medium qualification or high qualification and thus their income profile differs over the course of their lifetime (Bartus et al. 2013). In addition, several family benefits in Hungary depend on income or are at least tied to employment therefore in conjunction with the different educational levels these benefits offer quite different economic incentives for having children. Accordingly, we view the model separately for decision-makers representing an unskilled group (up to eight grades of elementary school), a group with low qualification (vocational training, vocational school), medium qualification (high school) and high qualification (higher education),

\footnotetext{
${ }^{2}$ We assume that the probability of infant mortality is zero.

${ }^{3}$ The trade-off between the number of children and the quality of children is addressed in the work of Becker (1993) and Bick (2010).
} 
and symbolise the highest completed level of education with the starting gross salary and productivity parameters. For men, we assume an exogenous productivity profile depending on age and qualification level. By contrast, the productivity profile for women is endogenous, because we factor in that she does not work during the period when she is raising a child and her human capital accumulated up to that point amortises (Bartus et al. 2013). For the sake of simplicity, we assume that the individuals making up a household have the same level of education. ${ }^{4}$ We estimated the productivity trajectory parameters in the 2010 and 2011 environment based on 2011 real gross wages and in the 2014 environment based on 2013 real gross wages for men and women and for every educational level.

We solved the basic model for three different support environments for each educational level under the family support regime prevailing in 2010, in 2011 and the new regime introduced in 2014 . The eligibility criteria for family benefits have changed substantially since 1 January 2014, and a new system that is more flexible in several points was adopted. In summary, all of the state tools that provide additional (disposable) income for families after they have children fall under the umbrella of family support; this concept therefore includes cash and family benefits ${ }^{5}$ and the family tax incentive system (according to the definition given by Ignits Kapitány 2006).

To the extent allowed by an abstract model, we attempted to realistically incorporate the eligibility rules for benefits under the old and new regimes, the amount of benefits, the prevailing taxation rules and the income trajectories by educational level. However, we ignored other transfers as they are not closely tied to our main topic. In summary, we made the following assumptions in our model:

- We distinguish for educational levels: unskilled (up to eight grades of elementary school), low qualification (vocational training, vocational school), medium qualification (high school) and high qualification (higher education).

- The father works during every period and throughout his time if he has at least a low level of education. Unqualified fathers only spend a portion of their time working.

- The mother does not work until the child is one year old, can decide on working when the child is between one and three years old and works full time once the child is older than three. Unqualified women are an exception to this and spend all of their time at home irrespective of age or number of children.

\footnotetext{
${ }^{4}$ There is empirical evidence that women with higher qualification typically choose a partner with higher qualification (Becker 1981; Bartus et al. 2013).

${ }^{5}$ Cash benefits include the prenatal allowance and the childcare allowance, while family benefits include the maternity allowance, the family allowance, childcare benefits and the child-raising allowance.
} 
- Daytime childcare for young children costs money.

- We consider the period between 18 and 37 years of age as the childbearing period for unskilled women and women with low education, between 20 and 39 years for women with medium education and between 25 and 44 years for women with high education.

In addition, we consider the following "fertility and labour life cycles" as the baseline and feel that these are an accurate reflection of reality for an average family with high, medium, low or no education: ${ }^{6}$

- A typical unskilled woman will have her first child at the age of 20, and we assume that she will remain inactive for the rest of her life.

- A typical woman with low education will have her first child at the age of 27, have two children consecutively and spend five years on average off the labour market.

- A typical woman with medium education will have one child at the age of 29 and spend three years off the labour market.

- A typical woman with high qualification (higher education) will have one child at the age of 31 and spend three years off the labour market.

In the following subchapters, we outline the costs and benefits of a family after they have children; we present the theoretical model that we built and its resolution, and finally we provide and calibrate the model's parameters.

\subsection{Costs and benefits of raising children}

Having and raising children is associated with the following direct and indirect costs for families in the model: ${ }^{7}$

- the consumption of children (direct)

- costs for daytime childcare for young children if the mother works (direct)

- the mother's lost current income during her years spent at home (indirect)

- the mother's human capital loss reflected in lower lifetime income (indirect)

- the one-off fixed cost of the mother's return to the labour market which increases with the number of children (representing the utility of household work) (indirect)

\footnotetext{
${ }^{6}$ We must emphasise that when interpreting the results, these assumptions will serve as a baseline but will not influence the results.

${ }^{7}$ András Gábos and Iván Gál Róbert factor similar components into the cost of raising children (Gábos - Gál - Keller 2007).
} 
From another perspective, having children is beneficial for families for the following reasons:

- The child is a source of joy. The instantaneous utility function is therefore positively dependent on the number of children.

- Families are eligible for numerous transfers if they have children (family support and social security cash benefits).

- Parents are also eligible for the family tax incentive if they have children.

\subsection{The household's decision-making problem}

\subsubsection{Lifetime utility}

The maximisable lifetime utility function takes on the following form in the model:

$$
V=\sum_{t=1}^{T_{i}} \beta^{t-1} u\left(c_{i t}, n_{i t}\right),
$$

where $0<\beta<1$ is the impatience parameter, $u(.,$.$) is the instantaneous utility$ function ${ }^{8}$ which is the unit of consumption expressed in money $\left(c_{i t}\right)$ and the additively separable function of the current number of children $\left(n_{i t}\right)$ :

$$
u\left(c_{i t}, n_{i t}\right)=\frac{\left(1+c_{i t}\right)^{1-\sigma}-1}{1-\sigma}+\Omega \frac{\left(1+n_{i t}\right)^{1-\varepsilon}-1}{1-\varepsilon},
$$

where $\sigma$ is the reciprocal of the intertemporal elasticity of substitution $(\sigma>0, \sigma \neq 1), \Omega$ shows the weight of the number of children within decision-making preferences and $\varepsilon$ measures how the utility function value reacts to changes in the number of children. In the lower index, $i$ refers to the type of household based on educational level while $T$ is the length of the examined life cycle, and $t$ pertains to the period under review. We assume that the man and the woman have the same level of completed education which may be one of the following four: unskilled, low, medium or high education, respectively shown as $i=0,1,2,3$. Irrespective of educational level, the life cycle decision to have children is investigated over a 20-year period, although this applies to the period between 18 and 37 years of age for unskilled individuals and those with low qualification, between 20 and 39 years of age for individuals with medium education and between 25 and 44 years of age for individuals with high education.

\subsubsection{Changes in the number of children over time}

$m_{i t} \in\{0,1\}$ is the number of children to be born during the period under review, which is equal to 0 if no children are born at the time $t$ and 1 if a child is born. If

\footnotetext{
${ }^{8}$ Bick (2010) and Jones (2010) used a form of function similar to ours. Bick and others included women's leisure time in the momentary utility function, but in our case, it is equal to zero.
} 
$m_{i t}=1$, then the number of children, $n_{i t}$ increases by one. Only one child can be born per year, that is

$$
n_{i t}=n_{i t-1}+m_{i t},
$$

assuming that the children outlive their parents.

\subsubsection{The budget constraint}

We assume that neither saving nor borrowing is possible and so the family spends all of the income after tax from the man's work (indicated in the upper index as $m$ ) and the woman's work (indicated in the upper index as $f$ ) and the transfers granted based on their children on consumption and if necessary for the children's daytime care and the other costs of starting work. Accordingly, the budgetary constraints for a family of type $i$ in the year $t$ under the 2010 regime will be:

$$
\bar{w} e_{i t}^{m} L_{i}^{m}+\bar{w} e_{i t}^{f} L_{i t}^{f}-T A X_{t}+T R_{t}=c_{i t}\left(1.7+0.5 n_{i t}\right)+p L_{i t}^{f}\left(m_{i t-1}+m_{i t-2}\right)+k\left(1-L_{i t-1}^{f}\right) L_{i t}^{f}
$$

where the man and the woman's gross wage is the real wage per efficiency unit $(\bar{w})$ obtained as a multiple of productivity $\left(e_{i t}^{m}, e_{i t}^{f}\right)$ and hours worked $\left(L_{i}^{m}, L_{i t}^{f}\right)$. The family pays tax during every period, the sum of which following deduction of the family tax allowance is $T A X_{t}$. All tax burdens are incurred differently under the various regimes due to changes in the family tax incentive and tax rules (see below). The benefits granted based on children further boost revenues, marked as $T R_{t}$ during the period $t$ (see below). The family must use its sources of income to cover all of its outlays, including its total consumption expressed as a multiple of a unit of consumption $\left(c_{i t}\right)$ and the OECD scale. ${ }^{9}$ Another expense is incurred if the mother returns to work when her child is between one and three years of age $\left(m_{i t-1}=1\right.$ or $\left.m_{i t-2}=1\right)$, in which case daytime childcare must be arranged; the unit cost of this expressed in hours worked is $p$. The mother's time spent at home is not only useful in terms of childcare, but also for performing household chores. This is symbolised by the cost $k$, which is the one-off cost of the mother returning to the labour market. The value of the parameter $k$ increases in parallel to the number of children.

Productivity profile. The man's productivity during his lifetime follows an exogenous trajectory depending on his age and education (Hotz et al. 1997; Attanasio et al. 2008; Keane - Wolpin 2010; Fehr - Ujhelyiova 2011). We describe developments in productivity as a function of the highest completed education (symbolised by the parameters $\left.a_{i}^{m}, \gamma_{i}^{m}\right)$, the amount of work experience $(t)$ and the productivity level of the previous period $\left(e_{i t-1}^{m}\right)$, similarly to the 2008 paper of Attanasio et. al.:

$$
e_{i t}^{m}=e_{i t-1}^{m} e^{\alpha_{i}^{m}+\gamma_{i}^{m} t}, \text { where } \alpha_{i}^{m}>0, \quad \gamma_{i}^{m}<0,
$$

\footnotetext{
${ }^{9}$ The OECD equivalence scale is the most prevalent in the literature, which assumes the consumption of the first adult among those sharing a household as one unit, the consumption of every additional adult as 0.7 units and the consumption of every child as 0.5 units (OECD 1982).
} 
where the function's parameters differ by educational level $(i)$. We also assume that the age of the man and the woman and their highest level of completed education are the same. The woman's productivity profile is defined endogenously because it depends on the labour supply decision also besides the qualification and the work experience (Attanasio et al. 2008). If the woman works during the period under review $\left(L_{i t}^{f}=1\right)$, then her knowledge acquired until then will increase relative to the previous period at the same rate as the man's, while if she does not work $\left(L_{i t}^{f}=0\right)$, then her productivity up to that point amortises at a rate of $\delta$, that is:

$$
e_{i t}^{f}=e_{i t-1}^{f} e^{\left(\left(\alpha_{i}^{f}+\gamma_{t}^{f} t L_{t}^{f}-\delta\left(1-L_{i t}^{f}\right)\right)\right.}, \text { where } \alpha_{i}^{f}>0, \gamma_{i}^{f}<0 \text {. }
$$

Amount of taxes under the 2010, 2011 and 2014 regimes. In 2010, personal income $\operatorname{tax}\left(\tau^{1}\right)$ was due based on the consolidated tax base (gross wage plus 27 per cent, also referred to as super gross) while social contributions (pension contribution $\left(\tau^{2}\right)$, health insurance contribution $\left(\tau^{3}\right)$, labour market contribution $\left(\tau^{4}\right)$ ) were charged to the gross wage (NAV 2016). There was also an opportunity for tax credits which we factored into the model. We specify the accurate parameters in Subchapter 2.4. The family tax incentive (indicated as $\operatorname{tax}^{1}$ per child) was granted as a tax rebate if a family had three or more children (Blaskó 2009). The total tax burden decreased by the family tax incentive can be calculated for 2010 as follows:

$$
T A X_{i t}^{2010}=\left(\tau^{1} \cdot 1.27+\tau^{2}+\tau^{3}+\tau^{4}\right)\left(\bar{w} e_{i t}^{m} L_{i}^{m}+\bar{w} e_{i t}^{f} L_{i t}^{f}\right)-n_{i t} \cdot \operatorname{tax}{ }^{1} .
$$

By 2011 the tax regime had become a single-rate regime, but super grossing and tax crediting were still employed. Contributions were still due based on the gross wage (NAV 2016). Starting from 2011, the family tax incentive for families with children the rate per child of which depends on the number of children and is represented by $\operatorname{tax}^{2}\left(n_{i t}\right)$ - is an item which reduces the tax base and is deducted from the super gross wage (NEFMI 2011). Accordingly, the total tax burden decreased by the family tax incentive can be calculated for 2011 as follows:

$$
T A X_{i t}^{2011}=\tau^{1} \cdot\left(1.27\left(\bar{w} e_{i t}^{m} L_{i}^{m}+\bar{w} e_{i t}^{f} L_{i t}^{f}\right)-n_{i t} \cdot \operatorname{tax}{ }^{2}\left(n_{i t}\right)\right)+\left(\tau^{2}+\tau^{3}+\tau^{4}\right)\left(\bar{w} e_{i t}^{m} L_{i}^{m}+\bar{w} e_{i t}^{f} L_{i t}^{f}\right)
$$

By 2014, super grossing was abolished, and thus personal income tax and contributions were also due based on the gross wage (NAV 2016). The family tax incentive remained as an item which reduced the tax base, but the tax incentive was expanded to encompass a family contribution incentive from 1 January 2014. Accordingly, if the family is unable to apply the full family incentive due to insufficient taxable income, it had the option to decrease its health insurance contribution, and later its pension contribution, by 16 per cent of the unapplied sum (or a portion thereof); we factored in the specific conditions of this regulation in solving the model (EMMI 2014). Total tax payable can thus be expressed based on $T A X_{i t}^{2014}$ as follows: 


$$
\begin{gathered}
T A X_{i t}^{2014}=\tau^{1} \cdot\left(\bar{w} e_{i t}^{m} L_{i}^{m}+\bar{w} e_{i t}^{f} L_{i t}^{f}-n_{i t} \cdot \operatorname{tax}^{2}\left(n_{i t}\right)\right)+\left(\tau^{2}+\tau^{3}+\tau^{4}\right)\left(\bar{w} e_{i t}^{m} L_{i}^{m}+\bar{w} e_{i t}^{f} L_{i t}^{f}\right)- \\
-0.16 \cdot\left(n_{i t} \cdot \operatorname{tax}^{2}\left(n_{i t}\right)-\bar{w} e_{i t}^{m} L_{i}^{m}+\bar{w} e_{i t}^{f} L_{i t}^{f}\right) .
\end{gathered}
$$

Size of transfers under the 2010 and 2011 regimes. If a child is born in a family $\left(m_{i t}=1\right)$, the mother first becomes entitled to a maternity allowance $\left(T R^{\circ}\right)$ as a guaranteed right (MÁK 2014). Until the child turns one, the mother receives a prenatal allowance ${ }^{10}$ (tgyás, represented by $T R_{t}^{1}$ ), which amounts to 70 per cent of the mother's real income earned in the year preceding the birth of the child and is only subject to the deduction of advance personal income tax $\left(\tau^{1}\right)$ :

$$
T R_{t}^{1}=\left(1-\tau^{1}\right) \cdot 0.7 \bar{w}_{i} e_{i t-1}^{f} L_{i t-1}^{f}
$$

(OEP 2014). However, if the mother has another child and does not return to the labour market between the two births, the most she can received after the second child is a prenatal allowance of $\overline{T R}^{1}$. Afterwards, the mother is eligible for the childcare benefit (gyed, represented by $T R_{t}^{2}$ ) until the child turns two, which also rises to 70 per cent of the mother's real income earned in the year preceding the birth of the child, which is also subject to a pension contribution payment obligation $\left(\tau^{2}\right)$ besides the advance personal income tax and its amount is maximised $\left(\overline{T R}^{2}\right)$, that is:

$$
T R_{t}^{2}=\min \left\{\left(1-\tau^{1}-\tau^{2}\right) \cdot 0.7 \bar{w}_{i} e_{i t-2}^{f} L_{i t-2}^{f} ; \overline{T R}^{2}\right\}
$$

(OEP 2014). During parental leave, the mother is eligible for childcare benefits (gyes) as a guaranteed right, which is a fixed sum and is only subject to the deduction of a pension contribution (represented, after the deduction of contributions, by $T R^{3}$ ). If the mother returns to work after the child turns one, she loses eligibility for the childcare allowance, but will become eligible for childcare benefits alongside her earned income ${ }^{11}$ (MÁK 2014). Families with three children receive childcare benefits during their entire life cycle, not only until the children turn three, ${ }^{12}$ which we took into consideration in our programming. The family receives a family allowance for every child from the time of their birth $\left(T R^{4}\left(n_{i t}\right)\right)$, which is a fixed sum and its amount depends on the number of children (MÁK 2014).

The amount of transfers under the 2010 and 2011 regimes ( $T R_{t}^{2010 / 2011}$ ) are determined as:

\footnotetext{
${ }^{10}$ In reality, the prenatal allowance is only granted in the first 24 weeks and from then on, the mother can apply for childcare allowance until the child turns one. For the sake of simplicity, we nevertheless assume in the model that the mother receives a prenatal allowance until the child turns one and childcare allowance when the child is between one and two years old.

${ }^{11}$ Here, we diverged from the actual policy, because under the 2011 regime, mothers could work up to 30 hours per week while receiving childcare benefits instead of full time.

12 In reality, this benefit is known as the child-raising allowance (gyet), which is in fact the same amount as the childcare benefit.
} 


$$
\begin{gathered}
T R_{t}^{2010 / 2011}=T R^{0} m_{i t}+T R_{t}^{1} m_{i t}+T R_{t}^{2} m_{i t-1}\left(1-L_{i t}^{f}\right)\left(1-m_{i t}\right)+T R^{3} m_{i t-2}\left(1-m_{i t-1}\right)\left(1-m_{i t}\right) \\
+T R^{4}\left(n_{i t}\right) n_{i t}
\end{gathered}
$$

In solving the model, we also factored in that the childcare allowance is only granted to the mother if she was insured before giving birth $\left(L_{i t-2}^{f}=1\right.$, or $T R_{t-2}^{1}=1$, or $T R_{t}^{2}=1$ ) and does not work when the child is between one and two years old. If the mother did not have valid insurance, she will still receive childcare benefits until her child turns two as follows:

$$
\begin{aligned}
& T R_{t}^{2010 / 2011}=T R^{0} m_{i t}+T R^{3} m_{i t}+T R^{3} m_{i t-1}\left(1-m_{i t}\right)+T R^{3} m_{i t-2}\left(1-m_{i t-1}\right)\left(1-m_{i t}\right)+ \\
& +\operatorname{TR}^{4}\left(n_{i t}\right) n_{i t}
\end{aligned}
$$

If there are several children under the age of three, the mother is only entitled to one benefit among the prenatal allowance, the childcare allowance and the childcare benefit under this regime.

Size of transfers under the 2014 regime. In the context of the extra childcare allowance (GYED-extra), the same benefits are available from 2014 and the amount of support (with the exception of the gyed maximum) and calculation method are the same. However, eligibility for these benefits changed significantly in two regards: one is that mothers can work full time while receiving the childcare allowance and the other is that the mother is eligible for several benefits if she had multiple young children. Accordingly, we calculate the amount of benefits under this family benefits scheme ( $T R_{t}^{2004}$ ) differently than earlier:

$$
T R_{t}^{2014}=T R^{0} m_{i t}+T R_{t}^{1} m_{i t}+T R_{t}^{2} m_{i t-1}+T R^{3} m_{i t-2}+T R^{4}\left(n_{i t}\right) n_{i t} .
$$

If the mother does not gain eligibility for the prenatal allowance and the childcare allowance, she can only receive childcare benefits during the first two years:

$$
T R_{t}^{2014}=T R^{0} m_{i t}+T R^{3} m_{i t}+T R^{3} m_{i t-1}+T R^{3} m_{i t-2}+T R^{4}\left(n_{i t}\right) n_{i t} .
$$

\subsubsection{Time constraint}

One usual assumption in the literature is that the man works full time during every period, that is $L_{i}^{m}=1$ (working time is normalised to one) (Hotz et al. 1997). We, however, only deem this assumption acceptable taking account of the stylised facts for a representative family of low, medium or high educational level $(i=1,2,3)$. By contrast, an unskilled breadwinner only spends 15 per cent of his time working during every period, that is, $L_{0}^{m}=0.15$. Among women, we distinguish between unskilled and qualified women. ${ }^{13}$

\footnotetext{
${ }^{13}$ See footnote 17 for an explanation of the choice of parameters.
} 
In the model, we assume that the unskilled woman does not work irrespective of whether or not she has a child, that is, $L_{0 t}^{f}=0$ during every period. If, however, the woman has at least a low educational level $(i=1,2,3)$, we use several limiting assumptions in her case. The woman's labour supply $L_{i t}^{f}$ can take on two discrete values, zero and one. If the family does not yet have or no longer has any young children, the woman works full time, that is:

$$
L_{i t}^{f}=1 \text {, if } m_{i t}, m_{i t-1}, m_{i t-2}=0 \text { and if } i=1,2,3
$$

We also assume that the woman does not work in the year of having the child, that is

$$
L_{i t}^{f}=0 \text {, if } m_{i t}=1 \text { and if } i=1,2,3 .
$$

However, if the mother's child is between one and three years old, she must make a decision on working (or having more children), considering the associated costs and benefits. In this case, the woman has two options: either working full time or raising the child full time:

$$
L_{i t}^{f}=\{0,1\} \text {, if } m_{i t-1}=1 \text { or } m_{i t-2}=1 \text { and if } i=1,2,3 .
$$

Although the change is radical between the two options, ${ }^{14}$ this assumption is not far removed from reality, as the part-time employment of women in Hungary is still low.

\subsection{Resolving the household's decision-making problem}

Resolving the household's dynamic problem can be expressed in the following manner. The household maximises its lifetime utility with the constraints presented in the previous chapter. The woman's decision-making problem to be represented using the following Belman equation:

$$
\begin{gathered}
V_{i t}^{L^{f t m}}=\max u\left(c_{i t}, n_{i t}\right)+\beta V_{i t+1}^{L^{t} m}, \quad \forall t<T_{i} \\
V_{i t}^{L^{t} m}=\max u\left(c_{i t}, n_{i t}\right), \quad t=T_{i}
\end{gathered}
$$

where $V^{t f m}$ is the value function. We resolve the model recursively, progressing backwards from the last period according to the dynamic programming model with the help of a MATLAB software package. In the model, the woman must make decisions throughout the life cycle on consumption $\left(c_{i t}\right)$, childbearing $\left(m_{i t}\right)$ and labour $\left(L_{i t}^{f}\right)$ in possession of the parameters and exogenous status variables $\left(L_{i}^{m}, e_{i t}^{m}\right)$. We also assume that the couple's decision is characterised by perfect foresight and that the family benefits scheme and tax rules under review (2006-2010, 2011-2013 or 2014) will remain in place throughout their lifetime. It is based on this that we are seeking the "best $m_{i t}-L_{i t}^{f}$ series of combinations" throughout the life cycle that

\footnotetext{
${ }^{14}$ While the mother receives childcare benefits, the employer has an obligation to take her back on the workforce with weekly working time of 30 hours at the mother's request.
} 
maximises the lifetime utility of the household of type $i$ under the specific family benefits scheme. When expressing a series of combinations, we factor in that one family can have up to three children. We then calculate the optimal fertility and labour strategy separately for 12 different scenarios - four educational levels and three family benefits schemes - that yields the highest lifetime utility.

\subsection{Selecting parameter values}

We set the model's parameters in terms of tax and social contribution rates and family benefits and the family tax incentive based on their actual value for all three periods and regimes. In the model, we regard one as HUF 100,000 and compare the other parameters expressed in money to this. The Appendix summarises the parameter values.

Under the 2010 regime, in the two-rate tax system, the personal income tax rate levied on labour income was 17 per cent for annual income of up to HUF 5 million $\left(\tau^{1}=0.17\right)$ alongside a certain tax credit $^{15}$ and for income of over HUF 5 million, 17 per cent for the portion of up to HUF 5 million and 32 per cent for the portion over HUF 5 million (in this case, $\tau^{1}=0.32$ ). The contributions were: 9.5 per cent pension contribution $\left(\tau^{2}=0.095\right), 6$ per cent health insurance contribution $\left(\tau^{3}=0.06\right)$ and 1.5 per cent labour market contribution ( $\tau^{4}=0.015$ ) (NAV 2016). The family tax incentive was HUF 4,000 per child ( $\left.\operatorname{tax}^{1}=0.04\right)$ in 2010 (SZMM 2010).

In 2011, the tax regime was a single-rate regime with a 16 per cent personal income tax rate (that is, $\left(\tau^{1}=0.16\right)$, but super grossing and tax crediting ${ }^{16}$ were still employed. Among contributions, only the pension contribution changed to $10 \mathrm{per}$ cent $\left(\tau^{2}=0.1\right)$, while the value of $\tau^{3}, \tau^{4}$ remained unchanged (NAV 2016). From 2011, the family tax incentive granted if a family had children was HUF 62,500 if there were one or two children, and HUF 205,000 if there were three or more children $\left(\operatorname{tax}^{2}\left(n_{i t}\right)=0.625 / 2.05\right)(N E F M I 2011)$.

In 2011, the personal income tax rate levied on gross wages was also 16 per cent $\left(\tau^{1}=0.16\right)$. Another change was the increase in the health insurance contribution to 7 per cent $\left(\tau^{3}=0.07\right)$, while all other contributions remain at their 2011 level. The family tax incentive remained unchanged between 2011 and 2014, but the tax incentive was expanded to encompass a family contribution incentive from 1 January 2014 (NAV 2016; EMMI 2014).

\footnotetext{
15 The tax credit was 17 per cent of the wage (but capped at HUF 15,100 ) and can be fully used if annual income is HUF 3,188,000; the tax credit then decreases for higher incomes. Annual incomes in excess of HUF 4,698,000 are not eligible for the tax credit (NAV 2016). We took into account the relevant threshold value for the tax credit.

${ }^{16}$ The monthly amount of the tax credit in 2011 was 12,100 at most, which can be used if annual income was $2,750,000$, while the rate of the tax credit decreased for higher incomes. Annual incomes in excess of HUF 3,960,000 are not eligible for the tax credit (NAV 2016).
} 
Because the man works all the time if his educational level is $i=1,2,3$ and working time is normalised to one, $L_{i}^{m}=1$ if $i=1,2,3$. For the unskilled, this is $L_{0}^{m}=0.15 .{ }^{17}$ For the sake of simplicity and easier comparison, we assume that real wage applied to the efficiency unit $\bar{w}=1$. In the model, we assume that daytime care for young children (in a public crèche, family day-care, private crèche or a babysitter) represents a cost of $p$ per unit of time for parents irrespective of their educational level if the mother returns to the labour market. We compare this value to the monthly cost of day-care for an average family, ${ }^{18}$ so we estimated a cost of HUF $50,000$ in 2011 and a cost of HUF 60,000 in 2014 ( $p=0.5 / 0.6)$. There is a shortage of capacity in public crèches and the existing crèches are overcrowded. If we take a closer look at the statistical data, it can be seen that in recent years 33-35 per cent of children in crèches were over three years old, ${ }^{19}$ which means that the children of mothers who would like to return to the labour market while receiving the childcare allowance or childcare benefits are partially crowded out. In addition, the family also faces a cost of $k$ that increases with the number of children if the mother resumes work: this cost reflects the utility of the household work performed during the mother's time spent at home. We do not differentiate this cost by educational level because we feel that it is not a function of education, but instead it differs individually based on how much and what level of household work is deemed useful for whom. ${ }^{20}$

We derived the baseline values of productivity and the parameter values based on actual cross-sectional data for 2011 for the 2010 and 2011 versions of the model and based on data for 2013 for the 2014 model in the following manner: In the model, the temporal productivity profile coincides with the developments in the gross wage over time, thanks to the $\bar{w}=1$ and $L_{i}^{m}=1$ assumptions, which allows us to estimate productivity parameters based on actual real earnings data. For every gender and for all four levels of education, the baseline productivity level at the beginning of the life cycle $\left(e_{i, 1}^{f}, e_{i, 1}^{m}\right)$ is based on the average starting gross real wage in 2011 and in 2013 for the 2014 version. ${ }^{21}$ For men, productivity follows an exogenous

\footnotetext{
${ }^{17}$ In the reference year 2011 the employment rate of males with education of less than eight years of elementary school was 9.7 per cent, while for those with education at most eight years of elementary school 28.7 per cent, for females the values were 4.7 and 17.8 per cent (KSH 2016). Based on this, we set the employment of males with education at most eight years of elementary school as 15 per cent, while for females it was 0 .

${ }^{18}$ We must dispel the myth that public crèche places can be accessed free of charge. Prior to 2011, payment could be requested for covering the raw material costs of meals and after 2011, a certain portion of overheads can be claimed from parents. Since 1 January 2012, the public operator can collect payment from parents for the daytime care of children. These fees apply over and above meal fees (Makay-Blaskó 2012).

${ }^{19}$ Calculated based on $\mathrm{KSH} 2014$.

${ }^{20}$ For instance, the importance or conversely, the substitutability of homemade meals for a family does not depend on educational level. For more on the calculation of the cost of household work, see Gábos et al. 2007.

${ }^{21}$ Fazekas - Benczúr - Telegdy (edit.) 2012:372, Figure 6.3.4. and Fazekas - Varga (edit.) 2015:238, Figure 6.3.4.
} 
trajectory. We determined the value of productivity parameters $\left(\alpha_{i}^{m}, \gamma_{i}^{m}\right)$ in such a manner that the exogenous trajectory of productivity most closely follows men's age-income profile by educational level in 2011 and in 2013 for the 2014 version. ${ }^{22}$

Women's productivity trajectory, which plays a role for women with low, medium and high qualification, is determined endogenously, because if the woman has a child and remains off the labour market, then her knowledge acquired until then amortises $(\delta)$ and depreciates. We use the values of Fehr and Ujhelyiova (2011) for the amortisation rate $(\delta)$, i.e. we assume 1 per cent for women with low qualification and 2 per cent for women with medium and high qualification. We first took into account when and how many children a typical woman of a given level of education has and how long she remains off the labour market. The estimation procedure is then identical to the procedure used for men. For women, we determined the value of productivity parameters $\left(\alpha_{i}^{m}, \gamma_{i}^{m}\right)$ in a manner that the "typical woman's" ${ }^{23}$ productivity trajectory most closely follows the age-income profile by educational level in 2011 and in 2013 given the baseline productivity values and the amortisation rate. ${ }^{24}$

The sum of family benefits for one month provides the monthly amounts used in the model. Accordingly, the value of the maternity allowance is $T R^{\circ}=0.053$, as we distributed HUF 64,125 proportionately over 12 months. The amount of the other benefits - the maximum prenatal allowance $\left(\overline{T R^{1}}\right)$ and childcare allowance $\left(\overline{T R^{2}}\right)$, childcare benefits $\left(T R^{3}\right)$, child-raising allowance $\left(T R^{3}\right)$, family allowance $\left(T R^{4}\right)$ - is defined by law; we used the relevant annual amounts for these items. For instance, if the net monthly child care benefit is HUF 25,600, we used $T R^{3}=0.265$ in the model. The values of the benefits provided under the family policy regimes under review are constant between 2008 and 2014.

The value of the impatience parameter is normally set between 0.9 and 1 for life cycle models (Attanasio et al. 2008; Bick 2010; Fehr - Ujhelyiova 2011). Similarly to the model of Attanasio et. al. (2008), we used 0.98 as the value of $\beta$. For the parameters of the utility function, we also used the standard values found in the literature when possible. The reciprocal of the intertemporal elasticity of substitution of consumption, $\sigma$, ranges between 1.5 and 2 , while $\varepsilon$, which measures how much the utility function reacts to changes in the number of children, is around 1.5. We used the values of Bick (2010): therefore we fixed $\sigma$ at 1.98 and $\varepsilon$ at 1.39 . Finally, in knowledge of the foregoing, we calibrated $\Omega$, the weight of the number of children within instantaneous utility so that - in line with the stylised facts - highly qualified families optimally had one child at the age of 31 in the 2010 environment,

\footnotetext{
${ }^{22}$ See: Fazekas - Benczúr - Telegdy (edit.) 2012:372/Figure 6.3.4. and Fazekas - Varga (edit.) 2015:238, Figure 6.3.4.

${ }^{23}$ See the list in Chapter 2.

${ }^{24}$ See: Fazekas - Benczúr - Telegdy (edit.) 2012:372/Figure 6.3.4. and Fazekas - Varga (edit.) 2015:238, Figure 6.3.4.
} 
while those with low qualification optimally had their child as young as possible. We uniformly use these values for the parameters associated with utility for all three household types/educational levels and all support environments. The Appendix provides a tabulated summary of the specific parameter values.

The majority of the taxation/labour market/productivity/family support parameters are estimated based on actual data, and therefore we did not subject them to robustness testing. An exception to this is the parameter representing daytime care for small children ( $p)$, in which a \pm 20 per cent divergence did not change our conclusions; in other words, our results can be regarded as robust for these parameter values. This is mainly due to the fact that for families of low and medium educational level, this cost is not incurred ${ }^{25}$ while for highly qualified families, this expenditure item is so small compared to income that a \pm 20 per cent divergence in the cost does not impact their decision. We also performed a sensitivity test for $\pm 5,10$ and 20 per cent divergences in the parameter $\Omega$ (the weight of the number of children in instantaneous utility). We address our results and interpret the tables in the following chapter.

\section{Simulation results}

Solving the model gives us an answer to the optimal number of children that a couple with a specific level of education should have during their lifetime and when they should optimally have them under the current benefits system, and when the mother should return to the labour market in order to maximise her lifetime utility. It should be noted once again that in the model we make the optimal strategy of having children conditional exclusively on the family support and taxation environment and the level of education, that is, we ignore all other parameters (such as changes in values or standards, the spread of new forms of relationships, cultural and biological factors and housing status) which, in reality, also shape the number of children and the timing of childbearing. Because other influencing factors are ignored, the model is only partially able to reflect the observable differences in the fertility patterns of families with differing characteristics. In summary, the results show the optimal number of children that a given family type should have and when they should optimally have them when considering the financial aspects only.

The decision on the right strategy is made by comparing the various temporal costs and benefits of having children. Childbirth in a family is, on the one hand, a value in and of itself, i.e. it represents a positive benefit throughout the family's lifetime. On the other hand, the parents become entitled to various benefits and allowances for many years (income effect), and therefore family benefits positively impact consumption and life cycle utility by increasing lifetime income. If the amount of benefits increases in parallel with the number of children, or if they become

${ }^{25}$ For families of low and medium educational level, we assume that the mother spends three years at home with her children and therefore, there is no need for daytime childcare. 
available only subject to a certain number of children, then the income effect is stronger (e.g. the system of tax allowances). But if the amount of benefit per child does not increase or increases only marginally in parallel with the total number of children, then the correlation is weaker (e.g. family allowance) (Gál 2011).

From another perspective, having children represents substantial expenses for the family. These expenses grow as the number of children increases. One of the parents - in reality most frequently, and also in the model, the mother - temporarily leaves the labour market after the child is born, meaning that she does not receive any income and the mother's expertise acquired until then is eroded during parental leave which will, in turn, setback her entire future life cycle earnings (substitution effect) (Jones et al. 2010; Gál 2011; Bartus et al. 2013), negatively impacting the family's life cycle consumption and thereby also its life cycle utility. As the number of children increases, the value of lost income from work and the mother's human capital amortises to a greater extent (Bartus et al. 2013). Moreover, with age and experience, the wage of those with a higher level of education increases much more dynamically than that of their peers with a lower level of education, and for this reason, they are likely to delay their intention to have children (postponement) in order to minimise the impact of the alternative cost of having children on their life cycle income ${ }^{26}$ (Bartus et al. 2013). Therefore, the substitution effect is greater overall in families with a higher level of education. However, this is compensated by the fact that the earning party in the family will have a higher lifetime income throughout his lifetime than a father with a lower educational level. The fact that the children also consume, just as the parents, and during early childhood they need day-care (direct cost) if the mother returns to the labour market, also represent additional costs. However, the model fails to consider that fact that the cost of child-rearing increases in parallel with the age of the children.

Overall, the optimal number of children and the optimal time of having them is obtained so that the family reaches the maximum lifetime utility resulting from the above-mentioned costs and benefits arising during the life cycle. It is of crucial importance as to what extent the amount of benefits and tax allowances received for the children can compensate the family's lost lifetime income and the direct costs associated with child-rearing. The costs and the benefits associated with having children differ for decision-makers with different educational levels and in the different family support and taxation environments, and for this reason, the optimal outcome will be different for each of them. In our analysis, we compare the values of the calculated life cycle utility in the different scenarios. We always take as a starting point the "typical fertility- employment life cycles" ${ }^{27}$ which we deem to best reflect reality in the case of an average family with high, medium and low educational level. We always compare the values of lifetime utility with the initial

\footnotetext{
${ }^{26}$ Aspects of economies of scale.

${ }^{27}$ We presented the typical fertility-employment life cycles in Chapter 2.
} 
case in such a way that, ceteris paribus, we modify some of our initial conditions. In the simulation, the final number of children, the mother's optimal age, the timing of having children and the length of parental leave are examined. First, we collectively examine the fertility strategy of individuals with low, medium and high educational level; we then separately analyse the change in the willingness to have children of unskilled couples.

When resolving the model, we took into consideration the current support and taxation environment for every regime, while we estimated the gross earnings based on the gross income paths based on education in 2011 and 2013 in the case of the support system in force in 2010/2011 and in 2014, respectively. However, in its current form, the model is unable to reflect the changes in real values (not adjusted by inflation), and therefore we should not draw conclusions in the case of the different regimes from the comparison of the absolute values of obtained life cycle utility. The model can, however, provide answers as to which family support environment incentivises more children, earlier employment or, in the case of more children, a faster timing to have children. In the following subchapter, we present the simulation results and the conclusions we can draw from them in the different cases.

\subsection{Optimal number of children}

Firstly, the main focus of the analysis is to find out how many actual children is optimal for the different family types during their lifetime in the different support and taxation environment in 2010, 2011 and 2014. For the purposes of the analysis, we considered the mother's time spent with her child/children as constant. The preconditions and the results of the simulation are presented in Table 1.

\section{Table 1}

Value of lifetime utility of the various types of families in the examined three benefits systems, in the cases of zero, one, two and three children

\begin{tabular}{|c|c|c|c|c|c|c|c|c|c|c|c|c|}
\hline \multirow{4}{*}{$\begin{array}{l}\text { Educational } \\
\text { level } \\
\text { Number of } \\
\text { children } \\
\text { Age } \\
\text { Leave (years) }\end{array}$} & \multicolumn{4}{|c|}{ High } & \multicolumn{4}{|c|}{ Medium } & \multicolumn{4}{|c|}{ Low } \\
\hline & zero & one & two & three & zero & one & two & three & zero & one & two & three \\
\hline & - & 31 & 31,33 & $31,33,35$ & - & 29 & 29,31 & $29,31,33$ & - & 27 & 27,30 & $27,30,32$ \\
\hline & - & two & two & two & - & three & three & three & - & three & three & three \\
\hline 2010 & 11.841 & 11.921 & 11.74 & 11.634 & 9.662 & 9.573 & 9.484 & 9.499 & 8.767 & 8.722 & 8.222 & 8.62 \\
\hline 2011 & 12.021 & 12.154 & 12.02 & 12.148 & 9.589 & 9.591 & 9.568 & 9.703 & 8.675 & 8.747 & 8.68 & 8.769 \\
\hline 2014 & 12.337 & 12.462 & 12.321 & 12.474 & 9.678 & 9.668 & 9.659 & 10.051 & 8.714 & 8.755 & 8.684 & 8.947 \\
\hline
\end{tabular}

Note: The educational level variable denotes the mother's and the father's highest completed educational qualification, while the number of children designates the final number of children in the family, the age indicates the mother's age at the time her child/children were born, and the years of leave variable denotes the number of years the mother spends at home with her children on maternity leave (gyes/gyed). 
Interpretation of the results can be facilitated if we first think over the underlying effect mechanisms. As the parameters of the utility function evolve independently from both the educational level and the family benefits system, having one child for any family type in any environment represents the same additional benefit. However, the financial costs of having children depends on the level of education and the support and taxation environment. Therefore, it is of key importance what percentage of the costs can be compensated by benefits and tax allowances after the birth of a child during the life cycle, and as such, what will be the consumption per unit in a family, as this is the other factor that influences utility. Compared to not having any children, upon having the first, the second and often the third child consumption per unit will be increasingly lower during the life cycle which means that the benefits and allowances only partially cover the costs. However, the joy associated with having children intensifies as the number of children increases. Lifecycle utility measures the total value of the current utility taken at present value, which stems from whether the damage caused by a decline in consumption due to having children or the joy takes precedence.

Accordingly, we can draw the following conclusions from the results of Table 1 . The utility of families with one child is higher in every case than that of families with two children, but it is not always higher than that of families without children. The tax allowance system in force between 2006 and 2010 available only for families with three or more children was so beneficial for families with low and medium educational level that it also encouraged families with only two children to have a third child. However, this was not the case for families with higher education having only two children. This was attributable to the fact that by having the third child, the life cycle consumption decreased only marginally or might have even increased compared to having only two children, although its rate still fell short of the life standard of families without children or only with one child. Overall, however, the joy associated with having children was able to compensate the negative effect of the lower consumption cycle for families with a lower level of education. Only in the case of families with higher education can we observe that families with one child were better off than those without children; in their case, this was attributable to the high value of the prenatal allowance and childcare allowance (tgyás and gyed) they received.

Thanks to the tax allowances which were extended in 2011 to families with one or two children, the situation improved in the sense that having the first child put these families in a better position than families without a child. Moreover, the tax allowance, which was substantially augmented for three children, reduced the cost of child-rearing for families of every educational level to such an extent that they could overall achieve higher lifetime utility with three children than with only two children, because by having the third child, their life cycle consumption 
did not decline, but on the contrary actually increased compared to having only two children. Although its value still lagged behind the living standard of families without children or only with one child, the joy associated with having children was able to compensate the reduced utility stemming from a lower consumption cycle. This is why we obtained the results according to which families with low and medium educational level with three children were even better off than having only one child. Our results also proved to be robust when the $\Omega$ parameter was changed as well.

The child benefit extra (GYED-extra) introduced in 2014 brought about additional improvement, as the benefits available at the expense of contributions further reduced the cost of having children, and so the system encouraged couples of every educational level to have three children. However, not even the measures of GYEDextra could improve the fact that "it is not worthwhile" to have a second child after the first one, as the position of families with two children, no matter what level of education, was worse than that of families with one child or without children. This is related to the fact that the birth of the second child represents a bigger burden for families (reduction of utility during the life cycle), even taking account of the supports and allowances, than the amount of joy they gain (increase in utility during the life cycle). This may mainly restrain the willingness to have children of those earning lower wages.

The described results can be regarded as robust within the \pm 20 per cent interval of the value of parameter $\Omega$ in the case of families with low educational level, and only within the \pm 10 per cent interval in the case of families with medium educational level. That is, in their case, a greater increase in the weight of the number of children tilts the scale in favour of families with two children compared to single-child families, but only in 2011 and 2014. We must handle the results for 2014 with caution for the group with higher education as they react sensitively to the change in $\Omega$ : if this is reduced by only 5 per cent, we can observe that three children do not provide a higher lifetime utility than a single child; there is only an improvement in comparison with childlessness and the two-children family model.

\subsection{Increasing age of mothers}

In the following, we analyse for families with one and two children whether the change in the support and taxation environment influences the optimal age of the mother in the case of couples with different educational levels. For the purposes of the analysis, we considered the mother's time spent with her child/children as constant, in the case of both one child and two children. 


\section{Table 2}

Value of lifetime utility of the various types of one-child families in the examined three benefits systems considered with advancing maternal age

\begin{tabular}{l|c|c|c|c|c|c|c|c|c}
$\begin{array}{l}\text { Educational } \\
\text { level }\end{array}$ & \multicolumn{3}{|c|}{ High } & \multicolumn{3}{c|}{ Medium } & \multicolumn{3}{c}{ Low } \\
\hline $\begin{array}{l}\text { Number of } \\
\text { children } \\
\begin{array}{l}\text { Age } \\
\text { Leave (years) }\end{array}\end{array}$ & one & one & one & one & one & one & one & one & one \\
\hline 2010 & 11.899 & 11.921 & 11.907 & 9.547 & 9.573 & 9.571 & 8.736 & 8.722 & 8.703 \\
\hline 2011 & 12.148 & 12.154 & 12.128 & 9.609 & 9.591 & 9.543 & 8.799 & 8.747 & 8.713 \\
\hline 2014 & 12.455 & 12.462 & 12.436 & 9.685 & 9.668 & 9.628 & 8.774 & 8.755 & 8.726 \\
\hline
\end{tabular}

Note: See Table 1.

According to Tables 2 and 3, under the family policy regime in 2011 and 2014, those who became parents at a younger age could achieve a higher lifetime utility (or the improvement was greater) than those having children at a later age, as in 2006, but only in the case of couples with low and medium educational levels. This stems from the fact that starting from 2011 in the case of those with lower education/wages, the family tax allowance also extended to families with one and two children, and the support available from 2014 in the form of contribution allowances was able compensate for the lost income at a younger age still. The described results are also considered robust when the value of parameter $\Omega$ changes by \pm 10 per cent. However, the value differences are not significant among the groups with either educational level.

\section{Table 3}

Value of lifetime utility of the various types of two-child families in the examined three benefits systems considered with advancing maternal age

\begin{tabular}{l|c|c|c|c|c|c} 
Educational level & \multicolumn{3}{|c|}{ High } & \multicolumn{2}{c}{ Medium } & \multicolumn{2}{c}{ Low } \\
\hline $\begin{array}{l}\text { Number of children } \\
\text { Age }\end{array}$ & $\begin{array}{c}\text { two } \\
27,29 \\
\text { Leave (years) }\end{array}$ & $\begin{array}{c}\text { two } \\
31,33 \\
\text { two }\end{array}$ & $\begin{array}{c}\text { two } \\
25,27 \\
\text { three }\end{array}$ & $\begin{array}{c}\text { two } \\
29,31 \\
\text { three }\end{array}$ & $\begin{array}{c}\text { two } \\
23,26 \\
\text { three }\end{array}$ & $\begin{array}{c}\text { two } \\
27,30 \\
\text { three }\end{array}$ \\
\hline 2010 & 11.659 & 11.74 & 9.409 & 9.484 & 8.211 & 8.222 \\
\hline 2011 & 11.971 & 12.02 & 9.574 & 9.568 & 8.754 & 8.68 \\
\hline 2014 & 12.27 & 12.321 & 9.671 & 9.659 & 8.696 & 8.684 \\
\hline
\end{tabular}

Note: See Table 1.

The legislative changes in 2011 and 2014 did not trigger a turning point for families with higher education. They can obtain higher lifetime utility in all three examined support environments if they have children above the age of 30 and not below.

A 5 per cent decrease in the parameter $\Omega$ shifts the optimal timing for having children in families with low and medium educational levels to an older age, but in their case, the results are also not sensitive to a 20 per cent increase in the 
parameter $\Omega$. By contrast, those who are highly qualified would have been better off having children at an increasingly younger age in 2011 and 2014 if parameter $\Omega$ increased by 5 per cent, but if the parameter decreases by 20 per cent, then the presented correlations do not change.

\subsection{Scheduling the time of having children}

In this sub-section, we compare the different scheduling of having children of families with three children. For the sake of the analysis, we fixed the mother's age in the case of the first child and only changed it for the second and third child, and we also considered the mother's time spent with her children at home as constant in every case.

\section{Table 4}

Value of lifetime utility of the various types of three children families in the examined three benefits systems in the case of different timing

\begin{tabular}{l|c|c|c|c|c|c|c|c|c}
$\begin{array}{l}\text { Educational } \\
\text { level }\end{array}$ & \multicolumn{3}{|c|}{ High } & \multicolumn{3}{c|}{ Medium } & \multicolumn{3}{c}{ Low } \\
\hline $\begin{array}{l}\text { Number of } \\
\text { children } \\
\begin{array}{l}\text { Age } \\
\text { Leave (years) }\end{array}\end{array}$ & $\begin{array}{c}31,33,35 \\
\text { two }\end{array}$ & $\begin{array}{c}31,33,37 \\
\text { two }\end{array}$ & $\begin{array}{c}31,35,39 \\
\text { two }\end{array}$ & $\begin{array}{c}29,31,33 \\
\text { three }\end{array}$ & $\begin{array}{c}29,31,35 \\
\text { three }\end{array}$ & $\begin{array}{c}29,33,37 \\
\text { three }\end{array}$ & $\begin{array}{c}27,30,32 \\
\text { three }\end{array}$ & $\begin{array}{c}27,30,34 \\
\text { three }\end{array}$ & $\begin{array}{c}27,32,36 \\
\text { three }\end{array}$ \\
\hline 2010 & 11.63 & 11.613 & 11.624 & 9.50 & 9.35 & 9.28 & 8.62 & 8.46 & 8.48 \\
\hline 2011 & 12.15 & 12.08 & 12.05 & 9.70 & 9.54 & 9.40 & 8.77 & 8.62 & 8.60 \\
\hline 2014 & 12.47 & 12.41 & 12.39 & 10.05 & 9.73 & 9.52 & 9.95 & 9.48 & 9.46 \\
\hline
\end{tabular}

Note: See Table 1.

Based on economic rationality, when having several children, families are better off financially if the children are born with the least age difference possible since this enables the mother to potentially stay away from work for a shorter period of time (less loss of human capital and also loss of life cycle income), and the family is able to use the tax allowance available for the three children sooner, or at least part of it.

The family policy regime between 2006 and 2010 did not significantly influence the timing of having children for highly qualified couples, but in certain cases a greater age difference may have been more beneficial: it is true that the tax allowance for families with three children became available only from a later period, but this was compensated by the fact that the mother could re-enter the labour market between children, and thanks to this, she received more pregnancy and maternity aid (tgyás) after the second and the third child (see first line of Table 4). But in the case of families with lower education, a smaller age difference between children clearly increases lifetime utility.

Highly educated couples who therefore earned high wages were incentivised for fast scheduling mainly by the tax allowance regime introduced in 2011, as they were already able to access a large part or the entire amount of the tax allowance under the 2011 regime. But the value of life cycle utility does not significantly change 
under either regime when modifying the timing of having children. By contrast, the measures of GYED-extra clearly incentivised couples with lower earnings (those with low and medium educational level) for faster timing of children bearing. This is explained by the fact that the family tax allowance, also extended as a contribution allowance, and the rule that the family could be entitled in parallel to family benefits for several young children could compensate the costs associated with having children to a greater extent. The described results are robust for the \pm 20 per cent change of the value of the parameter $\Omega$ for couples of every educational level. In this case, the optimal outcomes were not influenced by the pillar of the measures introduced in 2014 based on which the mother would be entitled to receive child benefit (gyed/gyes) even if she returned early to the labour market, because we assume in their case that the mother stays home for three years after the birth of every child. This enables us to separately analyse the components of GYED-extra.

\subsection{Increasing parental leave}

In the following, we compare the fertility strategies prevailing in the case when the mother's parental leave is increasingly long (one or three years). We present the analysis only for highly qualified couples with one, two or three children. The results obtained for couples with low and medium educational level are presented only in the essay part. In the simulation, we left the mother's age constant throughout the period examined.

\begin{tabular}{|c|c|c|c|c|}
\hline \multicolumn{5}{|c|}{$\begin{array}{l}\text { Value of lifetime utility of highly qualified families in the three examined benefits } \\
\text { systems, assuming increasing parental leave }\end{array}$} \\
\hline \multirow{2}{*}{\multicolumn{2}{|c|}{$\begin{array}{c}\text { Educational level } \\
\text { Support environment }\end{array}$}} & \multicolumn{3}{|c|}{ High } \\
\hline & & 2010 & 2011 & 2014 \\
\hline \multirow{2}{*}{$\begin{array}{l}\text { Number of children } \\
\text { Age } \\
\text { Leave (years) }\end{array}$} & $\begin{array}{c}\text { one } \\
31 \\
\text { one } \\
\end{array}$ & 12.03 & 12.266 & 12.603 \\
\hline & $\begin{array}{c}\text { one } \\
31 \\
\text { three } \\
\end{array}$ & 11.816 & 12.052 & 12.355 \\
\hline \multirow{2}{*}{$\begin{array}{l}\text { Number of children } \\
\text { Age } \\
\text { Leave (years) }\end{array}$} & $\begin{array}{l}\text { two } \\
31,34 \\
\text { one }\end{array}$ & 11.912 & 12.188 & 12.541 \\
\hline & $\begin{array}{l}\text { two } \\
31,34 \\
\text { three }\end{array}$ & 11.576 & 11.864 & 12.145 \\
\hline \multirow{2}{*}{$\begin{array}{l}\text { Number of children } \\
\text { Age } \\
\text { Leave (years) }\end{array}$} & $\begin{array}{c}\text { three } \\
31,34,37 \\
\text { one }\end{array}$ & 11.834 & 12.28 & 12.678 \\
\hline & $\begin{array}{c}\text { three } \\
31,34,37 \\
\text { three }\end{array}$ & 11.439 & 11.94 & 12.239 \\
\hline
\end{tabular}


For highly educated families, we obtained the rationally expected result that the less time the mother spent at home with her child/children, the better (in financial terms) for the family under all support schemes, provided that the mother had a job. In other words, higher lifetime utility can be achieved if the mother only spends one year at home with each of her children after they are born instead of two or three years.

Based on the table's results, it is also apparent that there is a stronger incentive for the mother's early return to the labour market in 2014 compared to 2010 and 2011 thanks to the fact that the mother does not lose the childcare allowance if she resumes work after her child turns one. The improvement between 2011 and 2014 is significant for both one, two and three children if measured by the percentage change in lifetime utility. In other words the childcare allowance extra (GYED-extra) measures foster a faster labour market return of mothers, which claim holds true for families with low and medium qualification. The described conclusions are robust for changes in parameter $\Omega$, as here, we assumed that the number of children and the constraints on childbearing are fixed.

\subsection{Childbearing among unskilled families}

According to the stylised data and thus also in the model, unskilled families behave differently, so we investigate them separately. We symbolise the unskilled couple using the following conditions: the mother remains an active throughout her lifetime irrespective of the number of children and the father also only works a part of the time. The following table summarises the value of lifetime utility if the family has one, two or three children paced differently.

\section{Table 6}

The value of lifetime utility of unskilled families under the examined three benefits systems, in case of one, two and three children

\begin{tabular}{l|c|c|c|c|c|c|c|c|c}
$\begin{array}{l}\text { Educational } \\
\text { level }\end{array}$ & \multicolumn{10}{|c}{ Uneducated } \\
\hline $\begin{array}{l}\text { Number of } \\
\text { children } \\
\text { Age }\end{array}$ & one & one & one & two & two & two & three & three & three \\
\hline 2010 & 18 & 23 & 28 & 18,20 & 18,22 & 18,24 & $18,20,22$ & $18,20,24$ & $18,20,26$ \\
\hline 2011 & 5.065 & 4.558 & 4.248 & 5.446 & 5.325 & 5.248 & 6.302 & 6.232 & 6.155 \\
\hline 2014 & 5.156 & 4.525 & 4.064 & 5.717 & 5.705 & 5.633 & 7.958 & 7.907 & 7.889 \\
\hline
\end{tabular}

Note: See Table 1.

Changes in family benefits schemes did not affect the optimal number of children in their case, nor did it significantly impact the timing of childbearing. By and large, the optimal strategy for them is to have as many children as possible (three children is better than one or two), as this entitles the mother to more benefits. In addition, 
it is best to have the children as young as possible and spaced close together, as this allows the family to take advantage of the benefits derived from the tax and contribution allowances applied to the father's income earned during his part-time work and to extend the eligibility period of the family allowance.

The results also show that the rise in the value of lifetime utility is more significant in 2011 compared to 2010, thanks to the tax incentive by having a second child after the first and a third child after the second. The measure, extended as a contribution incentive in 2014, yields a greater improvement than earlier by having a second child after the first, measured at a change in the value of lifetime utility. By contrast, families are unable to benefit from the high tax and contribution incentive granted for the third child to a greater extent, at which point "only" the childcare benefits and the family allowance provide an additional incentive.

\section{Results and conclusions}

In light of the results from the life cycle model, we are able to determine when and how many children different types of families, i.e. families of different educational levels should have, and when the mother should return to the labour market to achieve the maximum lifetime utility given the specific family support and tax regime. In other words, the model gives us an answer to how the multiple transformations of the family benefits scheme influences families' optimal childbearing and in what direction, with all other things being equal. Due to the differences in employment, we analysed the behaviour of families with low, medium and high qualification separately from the behaviour of qualified families. As a result, the first four points pertain to the first three family types while the last point addresses the fertility strategy of unskilled families.

1. The tax allowance system in force between 2006 and 2010 available only for families with three or more children was so beneficial for families with low and medium educational level that it also encouraged families with only two children to have a third child. However, this was not the case for families with higher education with only two children. From 2011, having the first child put these families in a better position than being childless. Furthermore, due to the significantly increased tax incentive for families granted for three children, all couples of every educational level could achieve higher lifetime utility than with two children. However, from 2014, we observed that having three children is clearly the most beneficial for families compared to having one child/being childless. However, a major impeding factor is that it is not "worthwhile" to have a second child after the first one in either support and taxation environment.

2. Among the family support tools introduced, the family tax incentive scheme introduced in 2011 has the greatest impact on optimal maternal age, as it makes 
it worthwhile to have children at a younger age for those with low and medium education.

3. Those with high qualification and thus high income were most incentivised to have children at a young age by the tax incentive adopted in 2011 while among lower-income families (medium and low qualification), the greatest incentive to having children early) were certain elements of the childcare allowance extra.

4. There was growing incentive for the mother's early return to the labour market after having a child from 2010 to 2011, and then to 2014 for all three educational levels.

5. For unskilled families, the optimal strategy under all three support regimes is to have as many children as possible spaced closely together and at the earliest possible age. The measures of the childcare allowance extra shaped the optimal outcome in that having a second child after the first one resulted in a greater improvement in lifetime utility than earlier.

Although we laid the foundations of the model, we do not feel that in its current state it is able to fully factor in and assess the impact of all economic and institutional factors shaping fertility choices. But building and stimulating the model brings us closer to understanding which support elements foster and contribute to childbearing from a financial perspective.

\section{References}

Arroyo, C. - Zhang, J. (1997): Dynamic Microeconomic Models of Fertility Choice: A Survey. Journal of Population Economics, 10: 23-65. https://doi.org/10.1007/s001480050030

Attanasio, O. - Low, H. - Sanchez-Marcos, V. (2008): Explaining Changes in Female Labor Supply in a Life-Cycle Model. American Economic Review, 98(4): 1517-1552. https://doi. org/10.1257/aer.98.4.1517

Bartus, T. - Murinkó, L. - Szalma, I. - Szél, B. (2013): The Effect of Education on Second Births in Hungary: A Test of the Time-Squeeze, Self-Selection, and Partner-Effect Hypotheses. Demographic Research, 28(1): 1-32.

Becker, G.S. (1981): A Treatise on Family. Cambridge. MA: Harvard University Press.

Bick, A. (2010): The Quantitative Role of Child Care for Female Labor Force Participation and Fertility. MPRA Paper No. 25474.

Blaskó, Zs. (2009): Családtámogatás, gyermeknevelés, munkavállalás (Family support, childrearing, employment). In: Monostori, J. - Őri, P. - Molnár, E. S. - Spéder, Zs. (editor): Demográfiai Portré 2009. Jelentés a magyar népesség helyzetéről (Report on the situation 
of the Hungarian population), Hungarian Demographic Research Institute of the Hungarian Central Statistical Office, Budapest. 41-53.

Del Boca, D. - Sauer, R. M. (2009): Life Cycle Employment and Fertility across Institutional Environments. European Economic Review 53: 274-292. https://doi.org/10.1016/j. euroecorev.2008.06.001

EMMI (2014): Family benefit, family contribution benefit 2014. Ministry of Human Capacities. http://emmiugyfelszolgalat.gov.hu/kereses?searchStr=csal\%C3\%A1di+ad\%C3\%B3kedvezm\% C3\%A9ny. Downloaded: 10 September 2014

Fazekas, K. - Benczúr, P. - Telegdy, Á. (edit.) (2012): Munkaerőpiaci Tükör 2012 (Hungarian Labour Market, 2012). HAS Institute of Economic Centre for Economic and Regional Studies, Országos Foglalkoztatási Közhasznú Nonprofit Kft. Budapest. www.bpdata.eu/ mpt/2012hua06_04. Downloaded: 12 October 2014.

Fazekas, K. - Varga, J. (edit.) (2015): Munkaerőpiaci Tükör 2014 (Hungarian Labour Market 2014). HAS Institute of Economic Centre for Economic and Regional Studies. Budapest. http://econ.core.hu/file/download/mt_2014_hun/egyben.pdf. Downloaded: 21 January 2016.

Fehr, H. - Ujhelyiova, D. (2011): Fertility, Female Labor Supply, and Family Policy. CESINFO Working Paper No. 3455.

Francesconi, M. (2002): A Joint Dynamic Model of Fertility and Work of Married Women. Journal of Labor Economics, 20(2): 336-380.

Gábos, A. (2005): A magyar termékenységi rendszer termékenységi hatásai (The impacts on fertility of the Hungarian fertility system). PhD dissertation, Corvinus University of Budapest, Sociology PhD programme. Budapest, 2005.

Gábos, A. - Gál, R.I. - Keller, T. (2007): A gyermeknevelés költsége és a társadalmi kompenzáció (The cost of child-rearing and social compensation). In: Mészáros, J. (editor): Családi jövedelemadózás. Budapest, Barankovics Alapítvány.

Gál, R.I. (2011): Fenntartható életpálya-finanszírozás. NFFT Műhelytanulmányok No 4.

Hotz, V.J. - Klerman, J.A. - Willis, R.J. (1997): The Economics of Fertility in Developed Countries: A Survey. Chapter 7. In: Handbook of Population and Family Economics. Volume A.: 275-347, Elsevier.

Ignits, Gy. - Kapitány, B. (2006): A családtámogatások alakulása: célok és eszközök (Evolution of family allowances: objectives and means). Demográfia, 49(4): 383-401. 
Jones, L.E. - Schoonbrodt, A. - Tertilt, M. (2010): Fertility Theories: Can they Explain the Negative Fertility-Income Relationship? In: Shoven, J.B. (ed.): Demography and the Economy. University of Chicago Press: 43-100.

Keane, M.P. - Wolpin, K.I. (2010): The Role of Labor and Marriage Markets. Preference Heterogeneity and the Welfare system in the Life Cycle Decisions of Black, Hispanic and White Women. International Economic Review, 51(3): 851-892. https://doi.org/10.1111/ j.1468-2354.2010.00604.x

KSH (2014): Hungarian Central Statistical Office: Tables (STADAT). Annual time-series data. Social safety-net. Table 2.4.10 http://www.ksh.hu/docs/hun/xstadat/xstadat_eves/i_ fsg005a.html. Downloaded: 10 September 2014.

KSH (2015): Annals of Demography 2014. Hungarian Central Statistical Office. Budapest.

KSH (2016): Hungarian Central Statistical Office: Tables (STADAT). Annual time-series data. Labour market. Table 2.1.44 http://www.ksh.hu/docs/hun/xstadat/xstadat_eves/i_qlf045.html. Downloaded: 5 January 2016.

Makay, Zs. - Blaskó, Zs. (2012): Családtámogatás, gyermeknevelés, munkavállalás (Family support, child-rearing, employment). In: Őri, P. - Spéder, Zs. (edit.) (2012): Demográfiai Portré 2012. Hungarian Demographic Research Institute of the Hungarian Central Statistical Office. Budapest: 45-56.

MÁK (2014): Családtámogatási ellátások (Family support allowances). Hungarian Treasury. http://www.allamkincstar.gov.hu/maganszemelyek/csaladtamogatas. Downloaded: 2 September 2014.

NAV (2016): National Tax and Customs Administration: Tax rates, contribution rates: Tax tables 2010-2016; Payable contributions 2010-2016. https://www.nav.gov.hu/nav/ szolgaltatasok/adokulcsok_jarulekmertekek. Downloaded: 13 January 2016.

NEFMI (2011): Családi adókedvezmény (Family tax allowances). Ministry of National Resources, Social and Information Department, Budapest.

OECD (1982): The OECD List of Social Indicators. OECD. PARIS. 1982.

OEP (2014): Az Egészségbiztositási Alapból támogatott ellátások (Benefits funded from the National Health Insurance Fund). National Health Insurance Fund. http://www.oep.hu/ portal/page?_pageid=34.66136161\&_dad=portal\&_schema=PORTAL. Downloaded: 30 September 2014.

SZMM (2010): Tájékoztató a gyermekek után járó ellátásokról (Information on the benefits for dependent children). Ministry of Social Affairs and Labour. Household Information and Advisory Department. Budapest, 2010. 


\section{Appendix: Summary table of parameter values}

\begin{tabular}{|c|c|}
\hline Description of parameter & Parameter value \\
\hline \multicolumn{2}{|c|}{ Taxation parameters } \\
\hline $\begin{array}{l}\text { Total taxes and contributions on gross wage- } \\
\text { related income }\end{array}$ & $\tau=0.345$ \\
\hline Personal income tax rate & $\tau^{1}=0.17 / 0.32 / 0.16$ \\
\hline Pension contribution & $\tau^{2}=0.095 / 0.1$ \\
\hline Health insurance contribution & $\tau^{3}=0.06 / 0.07$ \\
\hline Labour market contribution & $\tau^{4}=0.015$ \\
\hline $\begin{array}{l}\text { Rate of family tax allowance per child in } 2010 \text { (only } \\
\text { in case of three children) }\end{array}$ & $\operatorname{tax}^{1}=0.04$ \\
\hline $\begin{array}{l}\text { Rate of family tax allowance per child in case of } \\
\text { one, two or three children after } 2011\end{array}$ & $\operatorname{tax}^{1}\left(n_{i t}\right)=0.625 / 2.05$ \\
\hline \multicolumn{2}{|c|}{ Labour market parameters } \\
\hline Time spent working by an unskilled man & $L_{0}^{m}=0.15$ \\
\hline Time spent working by a man $(i=1,2,3)$ & $L_{i}^{m}=1$ \\
\hline Time spent working by an unskilled woman & $L_{0}^{f}=0$ \\
\hline Time spent working by a woman $(i=1,2,3)$ & $L_{i}^{f}=0 / 1$ \\
\hline Real wage for efficiency unit & $\bar{w}=1$ \\
\hline Cost of day-care of young children & $p=0.5 / 0.6$ \\
\hline $\begin{array}{l}\text { Fixed cost of re-entering the labour market in case } \\
\text { of one, two and three children }\end{array}$ & $k=0.5 / 0.7 / 0.8$ \\
\hline \multicolumn{2}{|c|}{ Productivity parameters } \\
\hline $\begin{array}{l}\text { Productivity of a highly qualified man during the } \\
\text { first period (2011/2013) }\end{array}$ & $e_{3,1}^{m}=2.172 / 2.498$ \\
\hline $\begin{array}{l}\text { Productivity of a medium skilled man during the } \\
\text { first period }(2011 / 2013)\end{array}$ & $e_{2,1}^{m}=1.207 / 1.374$ \\
\hline $\begin{array}{l}\text { Productivity of a low skilled man during the first } \\
\text { period }(2011 / 2013)\end{array}$ & $e_{1,1}^{m}=1.009 / 1.004$ \\
\hline $\begin{array}{l}\text { Productivity of an unskilled man during the first } \\
\text { period }(2011 / 2013)\end{array}$ & $e_{0,1}^{m}=1.013 / 9.45$ \\
\hline $\begin{array}{l}\text { Productivity of a highly qualified woman during } \\
\text { the first period (2011/2013) }\end{array}$ & $e_{3,1}^{f}=1.869 / 1.933$ \\
\hline $\begin{array}{l}\text { Productivity of a medium skilled woman during the } \\
\text { first period (2011/2013) }\end{array}$ & $e_{2,1}^{f}=1.078 / 1.205$ \\
\hline $\begin{array}{l}\text { Productivity of a low skilled woman during the first } \\
\text { period }(2011 / 2013)\end{array}$ & $e_{1,1}^{f}=0.927 / 0.901$ \\
\hline $\begin{array}{l}\text { Productivity parameters of a highly qualified man } \\
(2011 / 2013)\end{array}$ & $\begin{array}{c}\alpha_{3}^{m}=0.1226 / 0.097 \\
\gamma_{3}^{m}=-0.00693 /-0.0052\end{array}$ \\
\hline
\end{tabular}




\begin{tabular}{|c|c|}
\hline Description of parameter & Parameter value \\
\hline $\begin{array}{l}\text { Productivity parameters of a medium skilled man } \\
(2011 / 2013)\end{array}$ & $\begin{array}{c}\alpha_{2}^{m}=0.0636 / 0.058 \\
\gamma_{2}^{m}=-0.00301 /-0.003\end{array}$ \\
\hline $\begin{array}{l}\text { Productivity parameters of a low skilled man } \\
(2011 / 2013)\end{array}$ & $\begin{array}{c}\alpha_{1}^{m}=0.052 / 0.0766 \\
\gamma_{1}^{m}=-0.0027 /-0.00454\end{array}$ \\
\hline $\begin{array}{l}\text { Productivity parameters of an unskilled man } \\
(2011 / 2013)\end{array}$ & $\begin{array}{c}\alpha_{0}^{m}=0.01855 / 0.037 \\
\gamma_{0}^{m}=-0.00097 /-0.00185\end{array}$ \\
\hline $\begin{array}{l}\text { Productivity parameters of a highly qualified } \\
\text { woman }(2011 / 2013)\end{array}$ & $\begin{array}{c}\alpha_{3}^{f}=0.1 / 0.104 \\
\gamma_{3}^{f}=-0.0062 /-0.0062\end{array}$ \\
\hline $\begin{array}{l}\text { Productivity parameters of a medium skilled } \\
\text { woman }(2011 / 2013)\end{array}$ & $\begin{array}{c}\alpha_{2}^{f}=0.072 / 0.0705 \\
\gamma_{2}^{f}=-0.00375 /-0.00375\end{array}$ \\
\hline $\begin{array}{l}\text { Productivity parameters of a low skilled woman } \\
(2011 / 2013)\end{array}$ & $\begin{array}{c}\alpha_{1}^{f}=0.048 / 0.084 \\
\gamma_{1}^{f}=-0.0021 /-0.0046\end{array}$ \\
\hline $\begin{array}{l}\text { Amortization rate of low and medium skilled and } \\
\text { highly qualified persons }\end{array}$ & $\delta=0.01 / 0.02 / 0.02$ \\
\hline \multicolumn{2}{|c|}{ Family support allowances } \\
\hline Maternity support & $T R^{0}=0.053$ \\
\hline $\begin{array}{l}\text { Maximum net value of the prenatal allowance } \\
\text { (tgyás) }\end{array}$ & $\overline{T R}^{1}=1.3$ \\
\hline $\begin{array}{l}\text { Maximum net value of the childcare allowance } \\
\text { (gyed) }\end{array}$ & $\overline{T R}^{2}=0.808$ \\
\hline $\begin{array}{l}\text { Childcare benefit/child-raising allowance amount } \\
\text { (gyes/gyet) }\end{array}$ & $T R^{3}=0.256$ \\
\hline $\begin{array}{l}\text { Amount of family allowance per child in case of } \\
\text { one, two and three children }\end{array}$ & $T R^{4}=0.122 / 0.133 / 0.16$ \\
\hline \multicolumn{2}{|c|}{ Parameters related to utility } \\
\hline Impatience parameter & $\beta=0.98$ \\
\hline $\begin{array}{l}\text { The weight of the number of children within } \\
\text { current utility }\end{array}$ & $\Omega=0.123$ \\
\hline $\begin{array}{l}\text { Reciprocal of the intertemporal elasticity of } \\
\text { substitution of consumption }\end{array}$ & $\sigma=1.98$ \\
\hline $\begin{array}{l}\text { To what extent does the utility function react to } \\
\text { the change in the number of children }\end{array}$ & $\varepsilon=1.39$ \\
\hline
\end{tabular}

